\title{
Motivating Factors for Adult Learners in Higher Education
}

\author{
Olusegun Agboola Sogunro ${ }^{1}$, Ph.D. \\ ${ }^{1}$ Professor of Educational Leadership, School of Education and Professional Studies, Central Connecticut State \\ University, 1615 Stanley Street, New Britain, CT 06050, USA. Tel: 1-860-832-2131. Fax: 860-832-2109. E-mail: \\ sogunroo@ccsu.edu
}

Correspondence: Olusegun Agboola Sogunro, Ph.D., Professor of Educational Leadership, School of Education and Professional Studies, Central Connecticut State University, 1615 Stanley Street, New Britain, CT 06050, USA. Tel: 1-860-832-2131. Fax: 860-832-2109. E-mail: sogunroo@ccsu.edu

Received: October 22, 2014

Accepted: November 9, $2014 \quad$ Online Published: November 11, 2014

doi:10.5430/ijhe.v4n1p22

URL: http://dx.doi.org/10.5430/ijhe.v4n1p22

\begin{abstract}
All learners learn best when they are motivated; so do adults. Hence, the way to ensure success of students in higher education is first to know what motivates and sustains them in the learning process. Based on a study of 203 university students, this paper presents eight top most motivating factors for adult learners in higher education. These include quality of instruction; quality of curriculum; relevance and pragmatism; interactive classrooms and effective management practices; progressive assessment and timely feedback; self-directedness; conducive learning environment; and effective academic advising practices. The study concludes that these eight factors are critical to eliciting or enhancing the will power in students in higher education toward successful learning. The implications for practice and further research are also discussed.
\end{abstract}

Keywords: Higher education, Motivating factors, Adult learners, Andragogy, Pedagogy

\section{Introduction}

Gaining admission to a higher education institution is one thing, achieving academic success in a program of study is another thing. Many factors are critical to a student's success in higher education and motivation is one of those key factors. The reality is that in all teaching and learning transactions, motivation is an inevitable construct that evokes and sustains effective learning. According to Wlodkowski (2008), motivation is an important condition in learning-when it is low, potential for learning diminishes. In exploring the biology of learning, Zull (2002) concluded that motivation and learning are inseparable entities and from a motivational science perspective, Pintrich (2003) affirms a reciprocal relationship between motivation and academic achievement. Rotgans and Schmidt (2012) also corroborate the postulation of educational theories that an intricate relationship exists between motivation and achievement.

Although there is a realization that motivation cannot be seen, touched, or measured directly, several schools of thoughts believe that a positive relationship exists between motivation and adult learning (Benseman, 2005; Brookfield, 1986; Brophy, 2004; Deckers, 2005; Deshler, 1996; Hirsch, 2001; Kim \& Merriam, 2004; Knowles, Holton, \& Swanson, 2005; Wlodkowski, 1985, 1999, 2003, 2008). As explained by Wlodkowski (1999), "if we match two people of identical ability and give them identical opportunity and conditions to achieve, the motivated person will surpass the unmotivated person in performance and outcome" (pp. 3-4). This means that there is a causal factor--something causing one to behave in a particular way and that something is motivation. In other words, the higher the level of motivation, the more learning takes place.

Among many distinguishing characteristics, adult learners can be differentiated from other categories of learners simply by age. In the United States of America, a person is legally considered an adult at age 18. The Wikipedia (free encyclopedia) defines an Adult learner (North America) or mature learner (United Kingdom) (sometimes also called adult student, returning adult, adult returner, and student) as any person socially accepted as an adult who is in a learning process, whether it is formal education, informal learning, or corporate-sponsored learning. The UK National Adult Learning Survey 2010 has emphasized that adult learners are more likely than other groups of students to engage in further learning and to be motivated in doing so (BIS, 2012). However, beyond this we know and do little to motivate this group of learners (Brooks \& Everett, 2008). As posited by Collins (2009), whatever our perspectives on motivation, it is our responsibility as higher education instructors to help to enhance students' 
motivation to learn. In other words, we should always make conscientious efforts to prevent amotivation - something demotivational. That is, something causing a lack of drive, intent, excitement, or arousal to perform in certain ways or mere feelings that one's efforts may not yield desirable achievements (Deci \& Ryan, 1985; Deckers, 2005; Ryan \& Deci, 2000).

The literature is replete of research on how to motivate students in colleges and universities, especially at the undergraduate level (Bannier, 2010; Malacinski \& Winterman, 2012; Tan, 2007), but very scarce at the graduate level. Hence, the adult learners in this study are basically graduate students in various master's programs at Central Connecticut State University in New Britain, Connecticut, United States of America. Significantly, this study is predicated on identifying factors that are critical to motivating adult learners to achieve academic success in higher education.

The working definition of motivation as used in this study is: what stimulates and sustains a learner toward accomplishing educational goals overtime. Since adult learners in higher education generally prefer the use of facilitator or instructor to teacher, the word facilitator and instructor will be used interchangeably in this study. Also, since students in higher education programs are predominantly adults, the word adult learner will be used interchangeably with adult student. Colleges and universities are referred to as institutions of higher education.

\section{Literature Review}

According to Beck (2004), "The word motivation is derived from the Latin verb movere, which means to move. Motivation is then concerned with our movements, or actions, and what determines them" (p. 3). It is a broad theoretical concept that we often use to explain why people engage in particular actions at particular times (Beck, 2004). Schunk, Pintrich, and Meece (2008) define motivation as "the process whereby goal-directed activity is instigated and sustained" (p. 4). Thorkildsen (2002) defines motivation as "an internal force that activates, guides, and maintains behavior over time (p. ix). "Most psychologists concerned with learning and education use the word motivation to describe those processes that can (a) arouse and instigate behavior, (b) give direction or purpose to behavior, (c) continue to allow behavior to persist, and (d) lead to choosing or preferring a particular behavior" (Wlodkowski, 1985, p. 2).

Galbraith (1990) perceives motivation as a concept that helps us to understand human behavior and performance and as an unstable construct that cannot be directly measured or validated through the physical or natural sciences. According to him, most psychologists use the term motivation to describe those processes that can energize human behavior and give direction or purpose to a particular behavior. In other words, when we consider the human behavior in a learning setting, such as attention, concentration, effort, perseverance, and initiative, we are dealing with motivational processes that are activated and sustained through human energy while what we focus upon or pay attention to deals with the directional aspect of human motivation.

Viewing motivation as it relates to learning in colleges, McMillan and Forsyth (1991) define motivation as "purposeful engagement in classroom tasks and study, to master concepts or skills" (p. 39) and motivated students as those who "take learning seriously and try to get maximum benefits, rather than merely getting by or doing the minimum amount of work necessary" (p. 40). Deckers (2005) claims that motivation means "to be moved into action" or "to be moved into cognition, feeling, and action" (p. xiii) and that the source of motivation is what defines whether a behavior is intrinsically or extrinsically motivated and distinguishes between two types of motivation - intrinsic and extrinsic. According to Deckers (2005), intrinsic motivation is inherent in the activity being performed and is freely chosen by the individual while extrinsic motivation comes from external sources and is mostly driven or forced by environmental contingencies such as money, good grades, or the approval of others. Deckers (2005) concludes that the "Difference in the strength of some of these motives may predict students' persistence in university courses" and that "Behavior that began for extrinsic reasons later can be performed for its own sake - that is, for intrinsic reasons" (p. 277).

Schunk et al. (2008) claim that "Motivation is an important quality that pervades all aspects of teaching and learning" (p. vi). Research has revealed that adults' participation in higher education and other learning endeavors is predicated on motivation and that adult learners are motivated by diverse factors (Kim \& Merriam, 2004). In her book entitled "Learning and motivation in the postsecondary classroom," Marilla Svinicki (2004) postulates four ideas about what motivation does for learning including, directing learners' attention to the task at hand and making them less distractible; changing what learners pay attention to; helping learners' persistence when they encounter obstacles; serving as benchmarks that the learners can use to monitor their own learning and recognize when they are making progress and when they have finished a task. Svinicki also identifies four major theories of motivation that impact adult learning - deficit or drive-based, behaviorally-based, cognitive-based, and amalgamated (a composite of expectancy value model, social cognitive model, and goal orientation model). According to this author, early theorists depicted 
motivation as an inner force driving external behavior which increased when some type of imbalance or deficit in needs was felt by the learners. One such theory was known as drive theory-motivation to maintain physiological balance. That is, if organisms lacked water or food, their behavior would be directed toward correcting the ensuing imbalance. The drive theory was later expanded to include psychological needs (e.g., needs for approval, achievement, and affiliation) which keep thinking and behavior in balance. An imbalance between the two conditions (i.e., being at odds with each other) was called "cognitive dissonance."

Generally, it is easy to presume that "Motivation comes before behavior. But a behaviorist would say that what influences behavior is what comes after it, not before it. A behaviorist would say that reinforcement and punishment cause behavior" (Svinicki, 2004, p. 143). We motivate an individual by reinforcing or punishing targeted or expected behaviors. This strategy certainly is found in education at all levels in which students are praised and rewarded for their efforts toward expected behaviors. Students are rewarded with good grades when they perform well and with bad grades where they do not.

Toward the later part of the twentieth century, cognitive theorist engineered a shift in focus on motivation away from internal, pre-existing, semi-autonomous drives and needs to motivation being a function of how learners interpret a situation. They claimed that it was the learner's interpretation of a situation that determined whether he or she would be motivated by it and that the source of motivation primarily resides in both the learner and the environment with each influencing the other (Svinicki, 2004). This claim, according to Svinicki, is depicted by the amalgamated model which is a composite of three most prominent theories about motivation in use today (i.e., expectancy value model, social cognitive model, and goal orientation model) and guides instructors in designing instructional methods to motivate students. The expectancy value model portends that motivation involves a constant balancing of value and expectations for success and that both must be present for motivation to occur. However, their relative contributions vary from situation to situation. This balancing act is reflected in students' studying choices for grades. From the goal orientation perspective, the value of a learning goal is most obvious when it is achieved or when the outcome is most satisfying to the learner. The outcome may be a good grade, a higher salary, tenure, the satisfaction of a job well done or simply a satisfaction of an ambition. Behaviorists interpreted this type of motivation as manipulation of rewards and punishments and are easy for teachers to control. Social cognitive theorists claim that people's biases, interpretation of events, and expectations of reinforcements, impact their behavior" (Bandura, 1986; Stipek, 2002).

Most of the things that we can control are categorized as extrinsic motivators and are good at keeping a behavior going but over a long period, some intrinsic motivators are needed to keep the behavior (learning) strong and fresh. Svinicki (2004) asserts that learners' intrinsic motivation relieves the instructor of the task of constant supervision and reinforcement and reiterates motivation theorists' contention that if extrinsic motivation is provided for a behavior that was initially already intrinsically motivating, the tendency is high to kill the intrinsic motivation and thereby leave the learner dependent on the extrinsic motivator.

Historically, instructors have always known that when learners are motivated during the learning process learning is enhanced and many things go more smoothly--communication flows, anxiety decreases, and creativity becomes more apparent (Wlodkowski, 2008). In a sample of some 637, 000 students between ages six and eighteen (Grades 1-12) from 40 studies, Uguroglu and Walberg (cited in Wlodkowski, 2008) performed a benchmark analysis of 232 correlations of motivation and academic learning and found $98 \%$ positive correlations between motivation and academic achievement. The assumption that followed this finding was that if motivation could bear such a consistent relationship to learning for 18-year old students, it could probably have a similar relationship to adult learning. Further research in adult learning has proven that motivated adult learners are always interested in activities and strategies that will enhance their learning and reduce learning anxieties (Pintrich, 2003; Svinicki, 2004; Wlodowski, 1999, 2008; Zull, 2006).

Contextually in adult education, Knox's (cited in Merriam, 1993) proficiency theory "posits that motivation for adult learning is evoked by a discrepancy between current and desired levels of proficiency" (p. 10). Several studies assert that goal attainment is a manifestation of a student's capability for learning and motivation to set new challenging goals (Kim \& Merriam, 2004; Schunk et al., 2008; Svinicki, 2004; Wlodowski, 1999, 2008). According to Schunk et al. (2008), "Students who are motivated to learn often find that once they do, they are intrinsically motivated to continue their learning" (Schunk et al., 2008, p. 5).

With the view to applying motivation theories to practice in college teaching, McMillan and Forsyth (1991), proposed five assumptions to answer the question: "What do current theories of motivation offer college professors who want to enhance the purposeful engagement of their students?" (p. 40). First, with appropriate instructional behaviors and course structures, students can be motivated to greater involvement and higher achievement. Second, motivation 
concerns three fundamental questions: What initiates students' arousal or activity? What causes a student to move toward a goal? What causes a student to persist in striving toward a goal. Third, motivational theories tend to emphasize factors within individuals (i.e., traits or baggage of emotion that students bring to the classroom, such as fear of failure or anxieties and the strong need to achieve) or factors in the environment (i.e., the manner in which lectures are given, the competiveness of the grading system, or the rapport between the instructors and students and among students). Fourth, the assumption that no one motivational theory can be applied to every situation. Fifth, most theories of classroom motivation focus on learning needs or cognition (i.e., thoughts and mental processes) of students.

\section{Research Methodology}

\subsection{Participants:}

A total of 203 adult learners (37 males and 166 females) of diverse background, race, age, and profession (teachers, guidance counselors, school and college administrators, and university staff) participated in this study. Participants were all enrolled in various Master's degree programs, including Educational Leadership, Teacher Education (Elementary, Middle, and High Schools), Special Education, Counseling and Family Therapy, Modern Languages, and Physical Education and Human Performance. Of the 203 participants, 142 were White and 61 were Black. All participants have a minimum of a Bachelor's degree in their content areas. At the time of this study, about $90 \%$ had full time jobs as school teachers, guidance counselors, school and college administrators, and university staff. About $6 \%$ had part-time positions as substitute teachers, university staff, and day-home providers. About $4 \%$ were fulltime students.

\subsection{Data Collection and Analyses}

An exploratory mixed method research design was adopted for this study. In other words, a combination of both qualitative (i.e., focus groups and interviews) and quantitative (i.e., questionnaire) research methods was used to collect data. In an exploratory research design, qualitative data are collected before quantitative data (Creswell, 2012, 2014; McMillan \& Schumacher, 2010). That is, qualitative data are collected from a few individuals to identify themes, ideas, perspectives, and beliefs that can be used in designing the questionnaire part of the study (McMillan \& Schumacher, 2010). A basic advantage of this design is that the strengths of one form of data collection offset the weaknesses of the other form, provides the ease of triangulation of data sources, and consequently enhances the credibility of the findings (Creswell, 2008; Creswell \& Plano Clark, 2011; Teddlie \& Tashakkori, 2008).

The focus group discussions were held in order to gain an insight into the perceptions of adult learners regarding what motivates them in the learning process. As evident in this study, the focus group approach created a social environment that stimulated group members to volunteer information (i.e., through other members' feelings, perceptions, or ideas) that they would not express if interviewed individually. This approach increases the quality and richness of data (Gall, Gall, \& Borg, 2005; McMillan \& Schumacher, 2010). The interviews were held to gather in-depth information regarding the motivating factors gathered at both focus groups and questionnaire stages. In all, 63 adult learners participated in focus group discussions, 115 completed the questionnaire, and 25 were engaged in one-on-one interviews.

In fall 2007, three focus group discussions involving 63 students were facilitated in three graduate courses in the Educational Leadership program. Participants in the three focus groups were asked to identify three factors that motivate them in their learning. Perceptions were recorded and categorized into 14 themes. However, some of the 14 themes were observed to be overlapping, hence the need for clarification and merging of some of the themes. Finally, eight major themes or factors emerged (see Figure 1). These factors were used in the design of the questionnaire and will be discussed along with their implications for facilitators of adult learning later in this paper. The questionnaire was administered in 2008 (spring, summer, and fall semesters) to 143 adult learners who were registered in various graduate courses. The return rate was $80 \%$ (i.e., 115 students responded to the questionnaire). The data was entered into the Excel spread sheet and consequently analyzed to determine means, and standard deviations (see Table 1). The Statistical Package for Social Sciences (i.e., SPSS v16) was used for further analyses, especially to determine the Paired Samples Test. The paired $t$ test or a correlated group $t$ test is a type of $t$ test used to determine if the difference among the means were statistically significant (Suter, 2006).

Between summer 2008 and spring 2009, 25 students were engaged in one-on-one interviews. The interviews were semi-formal and were recorded in field notes and audiotapes. The audiotapes were transcribed and content analyzed using codes, emerging themes, and frequency counts. 


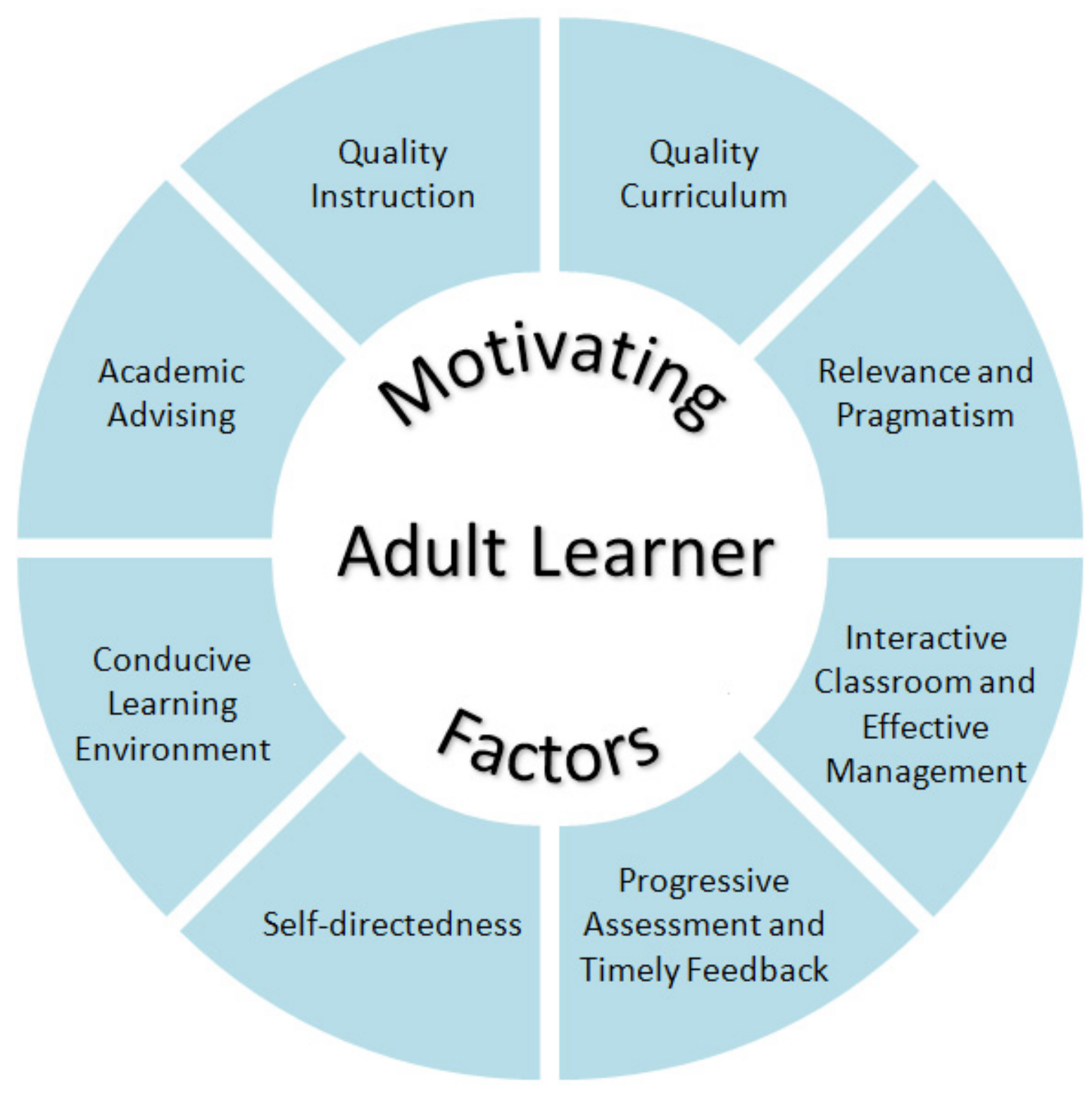

Figure 1. Motivating Factors for Adult Learners in Higher Education

\section{Discussion of Findings}

On a Likert-type scale, participants were asked to rate the eight categories of motivating factors identified earlier in the study (i.e., from 1: Least Important to 8: Most Important). Table 1 presents the results of the rating. 
Table 1. Motivating Factors for Adult Learners in Higher Education

$(\mathrm{N}=115)$

(8 Categories)*

\begin{tabular}{|l|l|l|}
\hline Motivating Factor & $\begin{array}{l}\text { Mean } \\
(\mathbf{M})\end{array}$ & $\begin{array}{l}\text { Standard Deviation } \\
\text { (SD) }\end{array}$ \\
\hline Quality of instruction & 1.44 & 0.71 \\
\hline Quality of curriculum (content/syllabus) & 3.28 & 1.97 \\
\hline Relevance and pragmatism & 3.88 & 1.93 \\
\hline Interactive classrooms and effective management practices & 4.18 & 1.60 \\
\hline Progressive assessment and timely feedback & 4.22 & 1.43 \\
\hline Self-directedness (Learner's autonomy) & 5.84 & 1.87 \\
\hline Conducive learning environment & 6.24 & 1.76 \\
\hline Academic advising practices & 6.68 & 1.71 \\
\hline
\end{tabular}

*8 Categories of Motivating Factors (from 1: Least Important to 8: Most Important).

The motivating factors in the table were arranged in a descending order of importance. These results reflect the relative importance of the eight motivating factors on adult learners in higher education.

The difference between the lowest and highest standard deviation values shows how participants differ in their perceptions about factors motivating adult learners in higher education. In other words, the large range of 1.26 (1.97-0.71) shows that there was a considerable disagreement among the adult learners as to which factor has the most impact on their learning in higher education. Of the eight factors identified, the low SD of 0.71 and the low mean value of 1.44 respectively show respondents' consensus of the relatively high value and high level of importance of the quality of instruction as a motivating factor toward learning. Compared to other seven factors, the mean value of 6.68 and a SD of 1.71 for academic advising practices indicated that participants were more in agreement that this variable was not as important as the quality of instruction and other factors.

As can be seen in the table, the top five motivating factors (i.e., quality of instruction, quality of curriculum, relevance and pragmatism, interactive classroom and effective management practices, and progressive assessment and timely feedback) recorded some relatively lower mean values of $1.44,3.28,3.88,4.18$, and 4.22 , respectively while the last three motivating factors (i.e., self-directedness, learning environment, and effective advising practices) had higher mean values of 5.84,6.24, and 6.68, respectively. From the perspective of the 115 respondents, this means that the top five factors were considered more critically important than the other three bottom factors.

To determine whether the means for each of the factors differ significantly from each other, a paired samples test (i.e., paired $t$ test or correlated groups $t$ test) was conducted for several pairs of means (see Table 2). The analysis netted 28 pairs and showed that there was no significant difference between the mean values of five pairs of factors (i.e., pairs 4, 6, 20,22, and 27). In other words, there was no significant difference between the mean values for conducive learning environment and academic advising practices $(p<.058)$; conducive learning environment and self-directedness $(\mathrm{p}<.090)$; progressive assessment and timely feedback and interactive classrooms $(\mathrm{p}<.840)$; progressive assessment and timely feedback and relevance and pragmatism $(\mathrm{p}<.186)$; and interactive classrooms and relevance and pragmatism $(\mathrm{p}<.228)$. That is, the significance levels of these set of pairs were higher than $\mathrm{p}<.05$. However, the analysis shows a statistically significant difference between the pair factors of quality of curriculum and relevance and pragmatism $(\mathrm{p}<0.36)$; and self-directedness and academic advising practices $(\mathrm{p}<.001)$. Moreover, in the paired sample tests, there was no significant difference between the pair factors of a conducive learning environment and academic advising practices and the pair factors of conducive learning environment and self-directedness. This statistical difference suggests that there is a difference as to how each factor impacts adult learners in higher education. In other words, each factor has its unique motivating effects on learning and impacts students differently. 
Table 2. Paired Samples Test

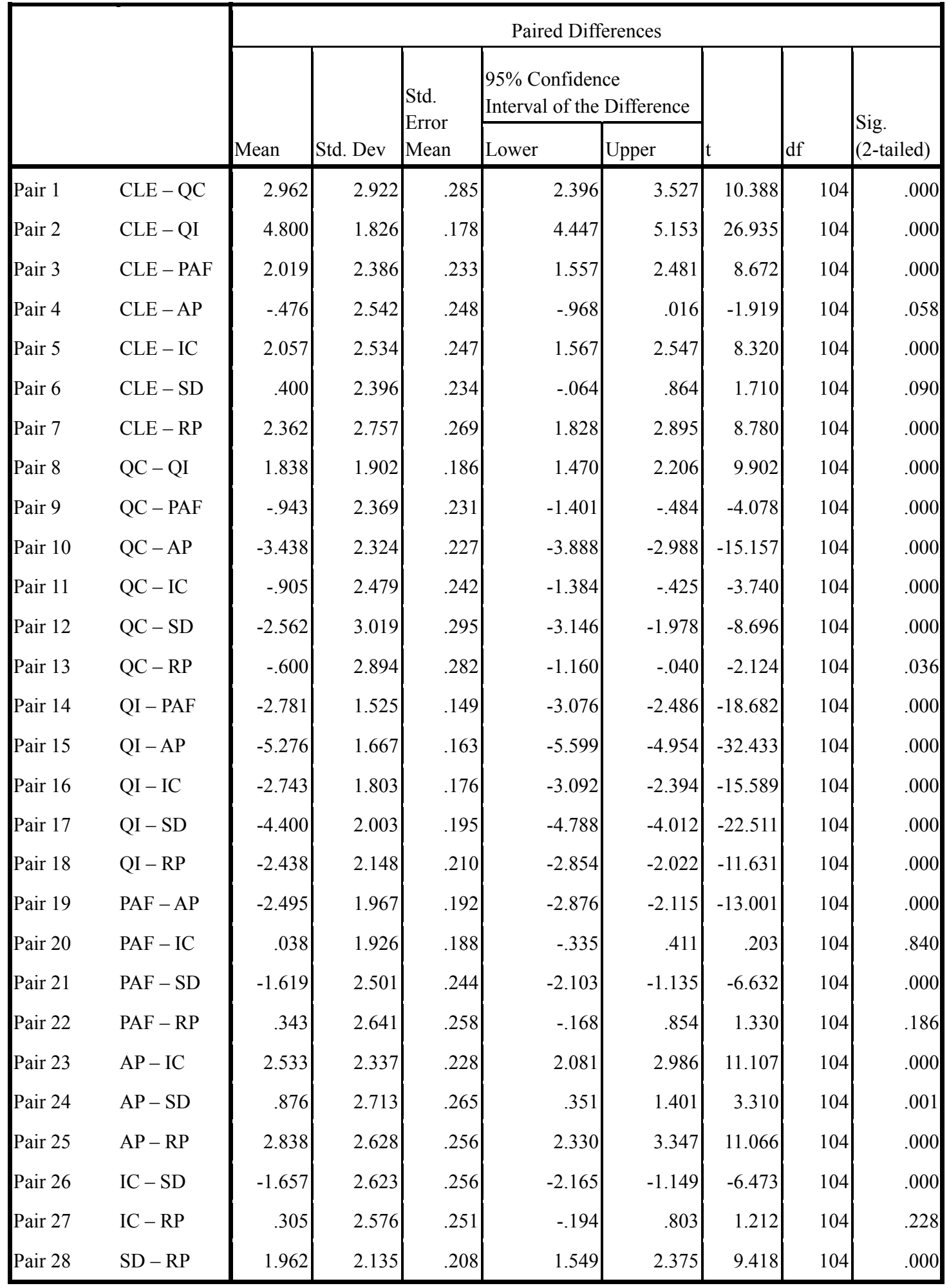

KEY: $\mathrm{AP}=$ Advising practices $\mathrm{SD}=$ Self-directed

PAF $=$ Progressive assessment $\&$ Timely feedback

QI = Quality of instruction

$\mathrm{IC}=$ Interactive classroom

$\mathrm{CLE}=$ Conducive learning environment

$\mathrm{QC}=$ Quality of curriculum

$\mathrm{RP}=$ Relevance $\&$ pragmatism 


\section{Eight Motivating Factors for Adult Learners in Higher Education}

The eight motivating factors identified in this study are all so important for adult learners in higher education that each factor individually merits some explications and reflections.

\subsection{Quality of Instruction}

More than $95 \%$ of the interviewees and about $70 \%$ of the respondents at the focus groups discussions claimed that the quality of instruction was the raison d'être for their participation in higher education. As earlier deciphered, a quality instruction embodies strong andragogical skills which includes effective planning and organization, manifestation of currency of knowledge of content, use of modern technology, and instructor's embracing personality attributes (e. g., communication - verbal and written, commitment, dedication, approachability, energy, empathy, care, empowerment, enthusiasm, humor, respect, and listening, and so on).

In many situations, it has been observed that effective instructional deliveries have aroused motivation in adult learners. For example, learners who feel motivated by a good instructional delivery relevant to their learning needs "seem more likely to have a continuous interest in and to use what they have learned" (Wlodowski, 2008, p. 6). As observed by Galbraith and Fouch (2007), adult learners have more life experiences, time demands, and psychological and socio-emotional barriers compared to children, hence the instructional approach for teaching in higher education should be more andragogical in nature. As stated by one of the respondents, "Instructors of higher education programs must be those who understand the complexities of adult life. They must be grown adults themselves and must be sensitive to adults learning styles and needs" (Interviewee AA).

\subsection{Quality of Curriculum}

Curriculum always precedes instruction. Curriculum (i.e., Syllabus or Course content) is critical to motivating adult learners in participating in any learning endeavors. More than $80 \%$ of the interviewees claimed that the quality of the curriculum was a major source of motivation for them. In higher education, curriculum is transposed into syllabus which contains specific information about a course of study, including goals and objectives; an outline and summary of topics to be covered in the course; schedule of class meeting times and class activities; expectations; evaluation criteria-- rubrics or grading standards; and instructor's contact information-- office hours, phone numbers, email addresses.

A program or course is of a high quality when the curriculum meets certain professional standards and learners' needs; and consequently yields satisfying results. As remarked by an adult learner during an interview, "I'm easily irritated and turned off when a syllabus is not geared to my felt needs and expectations. It amounts to a waste of time and money" (Interviewee BB). According to Kahler, Morgan, Holmes, and Bundy (1985), "Learning is influenced by whether it brings satisfaction or annoyance to the learner and that a thing learned is strengthened if the result is satisfying, and weakened if the result is annoying" (p. 23). Since syllabi are often prepared ahead of class meeting, the needs addressed are predominantly presumed and prescribed. Little or no attention is given to learners' felt or real needs. That is, the instructor designs the syllabus exclusively of learners' interests or immediate needs. To avoid such learners' displeasure, instructors should not make their syllabi a finished product needing no modifications. Rather, they should endeavor to infuse the learning needs and expectations of their students in the syllabi.

\subsection{Relevance and Pragmatism}

Relevance connects learning with reality. Generally, adult learners perceive learning as a means to an end and, therefore, value learning experiences only if they are relevant and applicable to their needs. In other words, a curriculum that lacks relevance and pragmatism is considered abstract, dull, and simply theoretical. As claimed by Apps (1991), "Most adult learners have a practical reason for their learning. They want to learn something that they can apply immediately" (p. 42). Therefore, they prefer problem-focused and hands-on-learning activities that are relevant to their immediate needs. As claimed by Wlodkowski (2003), relevance leads to what human beings generally experience as interest and when adult learners feel interested in what they learn, their motivation increases toward more meaningful learning.

More than $90 \%$ of the students interviewed emphasized the need for relevance of what they are taught to real life situations and their exposure to various applications of the materials learned. The following comments from three of the interviewees underscore the importance of course relevance and pragmatism in higher education:

If I am going to sit in a classroom at the university, I want to be able to use the information in my own classroom as a teacher. (Interviewee CC) 
Taking courses that offer an opportunity for skill development relevant to my job or promotion motivates me to learn. Meaningful tasks, clear goals, specific measures of success also motivate me to learn. (Interviewee $D D$ )

I am a pragmatist and a huge believer in constructivist principles. I truly think that adults learn best when they have hands-on in their learning. Students should be provided with as many authentic and performance-based activities as possible. (Interviewee EE).

In other words, adult learners prefer learning experiences that are experiential in nature. As advised by Svinicki (2004), instructors should find ways to enhance students' intrinsic motivation for the course they teach by showing them the connection between the course and their own interests as well as helping them understand how the course they take will give them an edge in the world of work.

\subsection{Interactive Classrooms and Effective Management Practices}

An interactive classroom and effective management practices were most cherishing to $92 \%$ of the interviewees. Interactive classrooms and effective management practices include classroom organization, enforcement of class expectations, and encouragement of verbalization of thoughts and cross fertilization of ideas among learners. Teaching of adults in higher education is most effective when it is interactive. As expressed by an adult learner: "I'm easily bored by long lectures. . . . I like to verbalize my ideas as well as listen to colleagues reflecting on their experiences" (Interviewee FF). In an interactive classroom, the need for adult learners to be accepted by the group increases their motivation toward learning. As claimed by Svinicki (2004), one thing that can influence students' motivation in a course is the degree to which the class becomes a community of learners. According to Svinicki, "When students feel they are part of the social group of the class and are working with others in the class to achieve similar ends, their motivation to participate is enhanced" (p. 148). This calls for instructors of adult learning to always strategically infuse small group activities as part of their instructional delivery.

Given the opportunity, adults like to discuss what they know about a problem or issue and ask questions for clarifications to deepen understanding. Among other things, adults prefer the student-centered or constructivism approach of instructional delivery whereby learners are more involved in the learning process than in the traditional approach. When teaching is mostly teacher-centered, it reminds adults of the notorious teaching practices reminiscent of the k-12 education they went through, and hence, becomes demotivating. As indicated by Toohey (1999), the establishment of cooperative and mutually supportive working relationships among students enhances motivation to learn, especially by establishing other routes to understanding than reliance on the instructor alone.

\subsection{Progressive Assessment and Timely Feedback}

Progressive assessment and timely feedback go hand-in-hand in motivating adult learners. As clarified during the focus group discussions, progressive assessment (e.g., grades, verbal and written comments) is continuous and reflects a learner's comprehensive performance in a course or learning activity while a timely feedback is one that is prompt and effective. According to Toohey (1999), adult learners are motivated when learning activities and assessment tasks are structured and sequenced in such a way to provide clarity about requirements and types of feedback. More than $90 \%$ of the interviewees and focus group participants held the view that a moderately segmented number of assessments followed by prompt and effective feedback are most motivating in any adult learning situation. Timely feedback is viewed as part of the learning process.

Psychologically, it is a well-established phenomenon that timely feedback furthers adult learning and "the more immediate and precise the feedback is, the stronger the effect on learning" (Boud \& Falchikov, 2007, p. 58). Perhaps because feedback from learning activities goes a long way to empower learners to be judges of their own academic progress and achievement, all the interviewees $(100 \%)$ in this study expressed the high motivating impact of timely and effective feedback in their learning. As diagrammatically represented in Figure 2, the Feedback Cycle is a three-stage iterative process among feedback, motivation, and enhanced performance, with the action of one inciting the other. The cycle begins and ends with feedback. That is, feedback arouses motivation which consequently triggers improvement of performance. Performance evokes another set of feedback and so the process continues cyclically. Apps (1991) emphasized the importance of honesty and diplomacy in giving feedback to adult learners in such a manner that will not be perceived as demoralizing and de-motivating. For example, "If a learner is not doing well, she or he deserves to know this, but we must present the message in such a way that the person doesn't give up" (p. 42). The key to motivating adult learners in this direction is to have clear expectations of performance, evaluation criteria, and rubrics at the beginning of instruction. As aptly stated by Brookfield (2006), "At a minimum, your syllabus should contain a summary of your expectations and assumptions as well as an unequivocal statement of the 
criteria you are applying to judge student work" (p. 8). As instructors, we can influence students' motivation for success by the way we provide feedback to the assignments we give them.

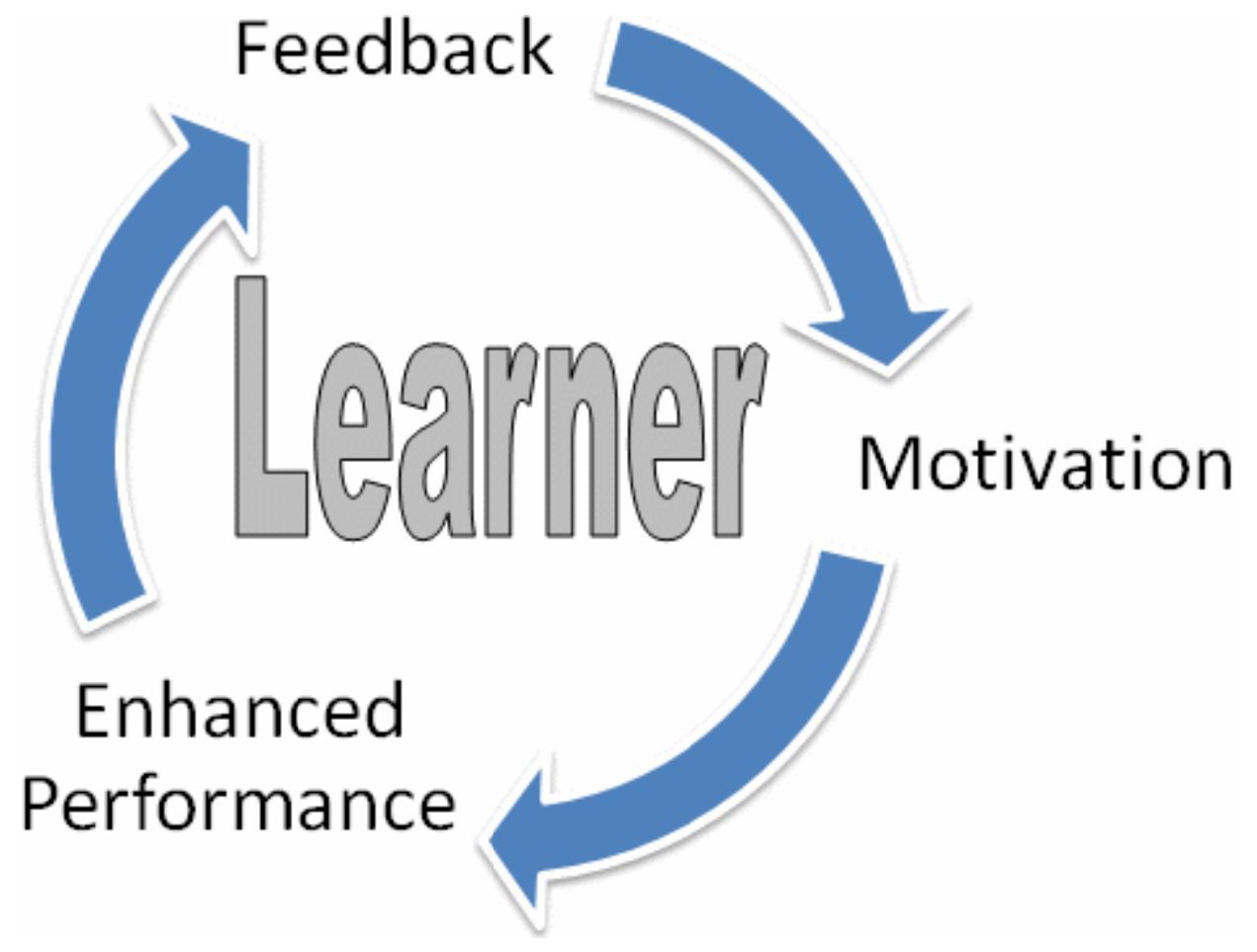

Figure 2. The Feedback Cycle

\subsection{Self-directedness (Learner's Autonomy)}

Self-directedness or autonomy is what motivates some adult learners in higher education. Hence, adult learners should be encouraged as much as possible to be responsible for their own learning. Mckendry and Boyd (2012) claim that the development of independent learning principle in higher education is of prime importance in motivating adults to learn. About $70 \%$ of the interviewees expressed preference for some latitude of autonomy in their learning endeavors. They advocated for flexible schedule for class meetings and more opportunities to make individual choices for their projects. In a research to examine the relationship between adult students' instructional technology competency and self-directed learning (SDL) ability, part of the results indicate that motivation is an important factor for adult learning. The results also show that students with higher level of self-directed learning ability are likely to exhibit higher level of self-efficacy and higher level of effort regulation toward learning and performance.

Generally, those who are self-directed are perceived to be self-determined and operate autonomously. According to Volkening, Ostermann, Link, and Hubner (2010), this varies with age. In a study to determine the impact of self-determination and directedness on adult motivation in continuing higher education in Germany (i.e., Occupational Therapists and Physiotherapists), Volkening et al. (2010) conclude that "The relation of autonomous and self-determined types of motivation is increasing with higher age" (p. 94).

One of Knowles's (1980) claims for andragogy (the art and science of helping adults learn) is that "adults have a deep psychological need to be generally self-directing" (p. 43). According to Knowles, this process of learning is otherwise referred to as "self-planned learning," "independent learning, " or "autonomous learning." Put another way, "Andragogy, and to some extent self-directed learning, is largely about the personal attributes of adult learners as opposed to children (Merriam, 2004, p. 206). That is, andragogy recognizes that the learning needs and characteristics of adult learners are diverse and different from those of the children.

Perhaps because of adult learners' prior knowledge and vast experience, they tend to prefer to take charge of their own learning and make necessary connections to new learning (Knowles, 1980). With these prior knowledge and experience, adult learners tend to place higher priority on internal motivators such as increased job satisfaction, higher self-esteem, and improved instructional delivery rather than external motivators such as salary increases, or pressures from bosses and peers (Knowles, et al., 2005; Tate, 2004). From the perspective of adult learning theory, 
Roberts and Pruitt (2003) assert that adult learners are autonomous in their learning needs and are much more in control of what they learn and how they learn. This assertion is corroborated by Knowles' (1989) proposition that adult learners have a self-concept of being responsible for their own learning. As claimed by three of the respondents,

Self-directedness is another way of saying I'm in control of my own destiny. . . . Although I sometimes feel overwhelmed, but I always find it challenging and intriguing to discover learning on my own. (Interviewee $G G$ ).

I would have to say I like to learn more on my own than anything else. I like to figure things out from experiences that I have. I have to admit that the dynamics of group work frustrates me quite a bit. (Interviewee $H H$ )

Noting that I'm required to take 30 credits (i.e., 10 courses or modules) for my Master's program in Educational Leadership, I would have loved to take two or three courses on-line or on weekends or a hybrid between weekends and online. (Interviewee II)

\subsection{Conducive Teaching and Learning Environment}

The learning environment manifests positive and negative effects on student motivation to learn. In a recent study to characterize the motivational orientation of students in higher education in three Hong Kong universities, Kember, Hong, and Ho (2008) characterized motivation as a framework with positive and negative poles that shifts as students progress through their degree programs according to their perceptions of the teaching and learning environment. Toohey (1999) claims that "The atmosphere within the classroom or lecture hall obviously has an effect on motivation" (p. 17) and that an alienating climate where students feel that no one cares about them or feels to know about their attendance will undermine their motivation to persevere to learn.

Seventy-two percent $(72 \%)$ of the interviewees were particular of the conduciveness of the teaching and learning environment. The traditional classroom sitting arrangements where students are arranged in groups of two, three, or four sitting side-by-side and sharing the same desk, all facing the teacher's desk and the notorious blackboard can be demotivating to many adult learners. For some, it reminds them of some horrible situations which they have experienced in the elementary, middle, or high schools. As expressed by a respondent: "I prefer those single chairs with big writing space" (Interviewee $J J$ ). This implies that higher education institutions should ensure adequate sitting arrangements and easy classroom movement for both instructors and learners.

The weather condition (coolness and hotness) of the classroom is an important factor in adult motivation to learn. As stated by two of the respondents: "My concern is the hot weather in summer. I can't stand the heat. . . and some of the classrooms are not air conditioned. This affects my concentration" (Interviewee KK). Another respondent exclaimed: "Learning in the cold can be deadly! The classroom must be well-heated in winter and air-conditioned in summer, otherwise there will be no serious learning taken place" (Interviewee $L L$ ).

The psychological impact of a safe, clean, modern, well equipped, and maintained classroom on learners cannot be underestimated. Some of the interviewees expressed how much they cherished the aesthetic environment of the university, especially with regards to the appealing landscapes, flowers, water fountains, and so on. Some mentioned the importance of such physical plants as elevators and wheelchair accessible classrooms. In their book on "Methods in adult education" Kahler et al. (1985) assert that "Students learn best if their environment is pleasant. ..." (p. 23).

\subsection{Effective Academic Advising Practices}

About $70 \%$ valued effective academic advising as critical to sustaining their motivation in the program. A good advisor guides and mentors. Without good advising, a student can be miserable, stressful, and have an unnecessary delay in graduation. Effective academic advising practices help to stir adult learners in the right direction and open window of opportunities that culminate into their success. Such motivation is often missing in many advising practices where facilitators lack the competence. Effective advising practices include working with students to select courses relevant to area of study, developing a "Planned Program of Study" (i.e., a sequence of course to be taken to graduate), and providing valuable information from time to time. The following comments by two of the interviewees speak to the importance of academic advising:

I view effective advising as a road map for a journey in the program. (Interviewee MM).

With the help of my advisor, I was able to transfer some credits from my former university to my program at this university. This has really saved me some money, time, efforts, and other things! (Interviewee $N N$ ). 
Among other things, effective advising practices help to increase graduation rates in higher education and should be taken seriously as an important endeavor in any institutions of higher education. In affirming the importance of student advisement in higher education, Central Connecticut State University in the United States of America, has recently proposed a new advising center where students will be better served with their academic programs and needs (Kiernan, 2009).

\section{Implications}

A critical implication is for policy makers at various institutions of higher education to show a realistic commitment to student motivation by providing quality curriculum and instruction, necessary learning resources such as libraries or laboratories, and guidance (Hirsch, 2001). Another important implication for practice is for facilitators of adult learning to be aware of the motivating factors identified in this study with the view to enhancing professional practices. In the 1970s and 80s, Knox (1986) claimed that most instructors in adult education programs were expert in their content areas and had little preparation in andragogical skills (i.e., how to teach adults). Today, the fact still remains that many instructors in higher education programs are stuck with pedagogical skills (i.e., how to teach children), and consequently tend to demotivate adult learners. For all practical and professional purposes, teaching at $\mathrm{K}-12$ level is different from teaching at college and university levels; hence, Harland's (2001) proposed academic apprenticeship for university lecturers is laudable. It becomes imperative for higher education institutions to organize regular professional development workshops in andragogical principles and practices for veteran and newly hired instructors in order to enhance their skills in teaching adult learners.

As once stated by Plato (428 BC-348 BC) an ancient Classical Greek Philosopher, "All learning has an emotional base." In other words, there is a relationship (positive and negative) between emotion and learning. In teaching and learning settings, positive mood or emotion can be motivating to some learners while negative mood or emotion can be demotivating to others. The moods or emotional behavior of individuals in a group situation can impact the emotions of others in the group, and consequently the group performance. This phenomenon is referred to as emotional contagion - "the process whereby the moods and emotions of those around us influence our own emotional state" (Kelly, 2004, p. 99). The impact of this phenomenon on adult motivation in learning needs further investigation.

Researchers have also attributed motivational sources to emotional intelligence (EI) such as persistence in adversity and motivations to support and connect with other people (Goleman, 1995; 2005; Salovey \& Mayer, 1990; Salovey, Mayer, \& Rosenhan, 1991; Schulze \& Roberts, 2005). Goleman $(1995,2005)$ explains EI as a manifestation of "abilities such as being able to motivate oneself and persist in the face of frustrations; to control impulse and delay gratification; to regulate one's moods and keep distress from swamping the ability to think; to empathize and to hope" (p. 34). Goleman argues that our EI determines our potential for learning and identifies its four fundamentals of EI-self awareness, self-management, social awareness, and the ability to manage relationships. Further studies are needed to determine the extent to which these fundamentals impact an adult's mood and learning potential or capability for attention, retention, mastery, and creativity. A corollary has been observed between emotional intelligence and multiple intelligences theory as they relate to motivation (Gardner, 1983, 1993; Engelberg \& Sjoberg, 2005). Particularly, the behavioral cues emanating from the intrapersonal and interpersonal intelligences are emotionally linked and tend to impact learning and achievement. According to Gardner (1999), "interpersonal intelligence denotes a person's capacity to understand the intentions, motivations, and desires of other people and, consequently, to work effectively with others" (p. 43) while "intrapersonal intelligence involves the capacity to understand oneself, to have an effective working model of oneself-including one's own desires, fears, and capacities - and to use such information effectively in regulating one's own life" (p. 43). Among other merits, the outcomes of such studies would help educators to adequately diagnose emotional challenges as well as determine appropriate intervention strategies and coping skills with which to enhance adult learners' motivation to learn.

The findings from this study have also prompted thoughts for determining motivational behaviors from different motivational sources including, cultural and demographic factors such as race and ethnicity, backgrounds, gender, religion, social class, marriage, and sexual orientation, to mention just a few. An interesting area of research is the determination of the impact of diverse cultural backgrounds in motivating learners in higher education. An example from personal experience is that cultural variations exist among adult learners that have backgrounds in Western cultures compared to those who do not. Adult learners that have backgrounds in Western cultures tend to be more independent and individualistic while those without manifest more interdependent and collectivist behaviors in their pursuit of higher education programs. In other words, some adult learners value individual efforts and self-reliance while some value group efforts and interactions. These cultural variations tend to have differing intrinsic and 
extrinsic motivating influences on students in higher education and, therefore, need further investigations. Another research interest is prompted by the increasing number of women in higher education today. Noting that more than $80 \%$ of the participants in this study were women, it is worthwhile to have studies that will investigate and explain the motivating factors responsible for having more women than men in higher education today. The question is: "Are women more motivated than men in the pursuit of higher education?" Other interesting general topics or research questions worth investigating include:

- Do cultural values such as religion affect adult learners' motivation in higher education?

- Is the level of motivation for higher education greater in one culture than the other?

- Does age impact adult learners' motivation in higher education?

- Does adult learners' social economic status affect their levels of motivation in higher education?

- Does emotional intelligence impact adult learners' motivation in higher education?

These studies are apt to further help higher education institutions in the development of programs appropriate for different groups of adult learners.

\section{Conclusion}

Predicated on the foregoing, evidence abounds that students who lack motivation tend to achieve low academic success in higher education. This study has brought to the fore eight factors that have potential to motivate students in higher education. These factors include quality of instruction, quality of curriculum, relevance and pragmatism, interactive classrooms and effective management practices, progressive assessment and timely feedback, self-directedness, conducive learning environment, and effective academic advising practices. They each have some motivationally productive impact on learning. The common theme running through the eight factors is their catalytic nature in motivating students to learn. In other words, students who are nestled in one or more of these eight motivating factors have the tendency of performing well in higher education. Hence, the knowledge and understanding of these factors are indeed compelling to all those who have stakes in higher education. However, more studies are needed to examine the relative impact of each of the factors on students' motivation in higher education.

The multifaceted definitions explicated in this paper point to the fact that motivation is indeed a concept that elicits or ignites the will power in a person to want to do. Thus, for all practical and intellectual purposes, this study has been able to establish the fact that these eight factors are critical to eliciting or enhancing and sustaining the will power in students in higher education to want to learn.

Overall, this paper contributes to the literature, an understanding of factors motivating adult learners in higher education. This understanding, especially by both instructors and administrators of higher education has the potential of enhancing the success of students pursuing graduate studies. Moreover, the study provides a useful starting point for further inquiry.

\section{References}

Apps, J. W. (1991). Mastering the teaching of adults. Malabar, FL: Krieger Publishing Company.

Bandura, A. (1986). Social foundations of thought and action: A social cognitive theory. Englewood Cliffs, NJ: Prentice-Hall.

Bannier, B. J. (2010, August). Understanding our adult, undergraduate learners: Designing course for success. Paper presented at the Annual Distance Teaching and Learning Conference, Madison, WI.

Beck, R. C. (2004). Motivation: Theories and principles ( $5^{\text {th }}$ ed.). Upper Saddle River, NJ: Prentice-Hall.

Bensemen, J. (2005). "Participation.” In L. English (Ed.). International encyclopedia of adult education. New York: Palgrave Macmillan.

BIS (2012, October). UK National Adult Learning Survey 2010. London: Department for Business, Innovation and Skills. Retrieved August 10, 2014 from

https://www.gov.uk/government/uploads/system/uploads/attachment_data/file/34798/12-p164-national-adult-learnersurvey-2010.pdf.

Boud, D. \& Falchikov, N. (Eds.). (2007). Rethinking assessment in higher education: Learning for the longer term. New York: Routedge. 
Brookfield, S. D. (1986). Understanding and facilitating adult learning. San Francisco: Jossey-Bass.

Brookfield, S. D. (2006, Fall). Authenticity and power. In P. Cranton. Authenticity in teaching. New Directions for Adult and Continuing Education, 111, 5-16. http://dx.doi.org/10.1002/ace.223

Brooks, R. \& Everett, G. (2008, May-June). The impact of higher education on lifelong learning. International Journal of Lifelong Education, 27(3), 230-254. http://dx.doi.org/10.1080/02601370802047759

Brophy, J. (2004). Motivating students to learn (2 ${ }^{\text {nd }}$ ed.). Mahwah, NJ: Erlbaum.

Collins, N. (2009, July/August). Motivation and self-regulated learning. The Journal of Higher Education (Columbus, Ohio), 80(4), 476-479. http://dx.doi.org/10.1353/jhe.0.0057

Creswell, J. W. (2008). Educational research: Planning, conducting, and evaluating quantitative and qualitative research. Upper Saddle River, NJ: Pearson.

Creswell, J. W. (2012). Educational research: Planning, conducting, and evaluating quantitative and qualitative research (4th ed.). Boston: Pearson.

Creswell, J. W. (2014). Research design: Qualitative, quantitative and mixed methods approaches (4th ed.). Thousand Oaks, CA: Sage.

Creswell, J. W. \& Plano Clark, V. L. (2011). Designing and conducting mixed methods. Thousand Oaks, CA: Sage.

Deci, E. L. \& Ryan, R. M. (1985). Intrinsic motivation and self-determination in human behavior. New York: Plenum Press. http://dx.doi.org/10.1007/978-1-4899-2271-7

Deckers, L. (2005). Motivation: Biological, psychological, and environmental ( $2^{\text {nd }}$ ed.). Boston: Pearson.

Deshler, D. (1996). "Participation: Role of motivation.” In A. C. Tuijnman (Ed.). International encyclopedia of adult education and training ( $2^{\text {nd }}$ ed.). New York: Pergamon Press.

Engelberg, E. \& Sjoberg, L. (2005). Emotional intelligence and inter-personal skills. In R. Schulze \& R. D. Roberts (Eds.). Emotional intelligence: An international handbook. Ashland, OH: Hogrefe.

Galbraith, M. W. (1990). Attributes and skills of an adult educator. In M. W. Galbraith (Ed.). Adult learning methods (pp. 3-22). Malabar, FL: Krieger Publishing Company.

Galbraith, D. \& Fouch, S. (2007, September). Principles of adult learning: Application to safety training. Professional Safety, 52(9), 35-40.

Gall, J. P, Gall, M. D., \& Borg, W. R. (2005). Applying educational research: A practical guide ( $8^{\text {th }}$ ed.). Boston: Pearson.

Gardner, H. (1983). Frames of mind. New York: Basic Books.

Gardner, H. (1993). Frames of mind: The theory of multiple intelligences ( $2^{\text {nd }}$ ed.). New York: Basic Books.

Gardner, H. (1999). Intelligence reframed: Multiple intelligences for the $21^{\text {st }}$ century. New York: Basic Books.

Goleman, D. (1995). Emotional intelligence: Why it can matter more than IQ. NY: Bantam Books.

Goleman, D. (2005). Emotional intelligence: Why it can matter more than IQ. NY: Bantam Books.

Hartland, T. (2001, November). Pre-service teacher education for university lecturers: The academic apprentice. Journal of Education for Teaching, 27(3), 269-276. http://dx.doi.org/10.1080/02607470120091597

Hirsch, G. (2001). Helping college students succeed: A model for effective intervention. Philadelphia, PA: Brunner Routledge.

Kahler, A. A., Morgan, B., Holmes, G. E. \& Bundy, C. E. (1985). Methods in adult education. Danville, IL: The Interstate Printers \& Publishers, Inc.

Kelly, J. R. (2004). Mood and emotion in groups. In M. B. Brewer \& M. Hewstone (Eds.). Emotion and motivation (pp. 96-112). Malden, MA: Blackwell.

Kember, David, Hong, Celina, \& Ho, Amber (2008, June). Characterizing the motivational orientation of students in higher education: A naturalistic study in three Hong Kong universities. The British Journal of Educational Psychology, 78(2), 313-330. http://dx.doi.org/10.1348/000709907X220581

Kiernan, M. (2009, April). Administration is gearing up for fall advising improvements: Center for student success on the way. The Recorder, 105(25), 1-2. 
Kim, A. \& Merriam, S. B. (2004). Motivations for learning among older adults in a learning in retirement institute. Educational Gerontology, 30, 441-455. http://dx.doi.org/10.1080/03601270490445069

Knox, A. B. (1986). Helping adults learn: A guide to planning, implementing, and conducting programs. San Francisco: Jossey-Bass.

Knowles, M. S. (1980). The modern practice of adult education: From pedagogy to andragogy (2nd ed.). New York: The Association Press.

Knowles, M. S., Holton, E. F., \& Swanson, R. A., (2005). The adult learner: The definitive classic in adult education and human resource development. San Diego, CA: Elsevier.

Malacinski, G. M. \& Winterman, B. (2012). Engaging and motivating undergraduate science students in a writing workshop designed to achieve information literacy and professional level competence. International Journal of Arts \& Sciences, 5(6), 397-414.

McKendry, S. \& Boyd, V. (2012). Defining the "independent learner" in UK higher education: Staff and students' understanding of the concept. International Journal of Teaching and Learning in Higher Education, 24(2), 209-220.

McMillan, J. H. \& Forsyth, D. R. (1991, Spring). What theories of motivation say about why learners learn. In R. J. Menges \& M. D. Svinicki (Eds.). College teaching: From theory to practice. New Directions for Teaching and Learning, 45, 39-52.

McMillan, J. H. \& Schumacher, S. (2010). Research in education: Evidence-based inquiry ( $7^{\text {th }}$ ed.). Boston: Pearson.

Merriam, S. B. (2004). The changing landscape of adult connecting research, policy, and practice. Review of Adult Learning and Literacy, 4, 199-220.

Merriam, S. B. \& Caffarella, R. S. (1991). Learning in adulthood: A comprehensive guide ( $2^{\text {nd }}$ ed.). San Francisco: Jossey-Bass.

Mezirow, J. \& Associates (1990). Fostering critical reflections in adulthood. San Francisco: Jossey-Bass.

Pintrich, P. R. (2003). A motivational science perspective on the role of student motivation in learning and teaching contexts. Journal of Educational Psychology, 95, 667-686. http://dx.doi.org/10.1037/0022-0663.95.4.667

Plato (428 BC-348 BC). All learning has an emotional base. Retrieved December 10, 2012, from http://thinkexist.com/quotation/all_learning_has_an_emotional_base/294477.html

Roberts, S. M. \& Pruitt, E. Z. (2003). Schools as professional learning communities: Collaborative activities and strategies for professional development. Thousand Oaks, CA: Corwin Press.

Rotgans, J. I. \& Schmidt, H. G. (2012). The intricate relationship between motivation and achievement: Examining the mediating role of self-regulated learning and achievement-related classroom behaviours. International Journal of Teaching and Learning in Higher Education, 24(2), 197-208.

Ryan, R. A. \& Deci, E. L. (2000). Self determination theory and the facilitation of intrinsic motivation, social development, and well-being. American Psychologist, 55, 68-78. http://dx.doi.org/10.1037/0003-066X.55.1.68

Salovey, P., Mayer, J. D. (1990). Emotional intelligence. Imagination, Cognition, and Personality, 9(3), 185-211. http://dx.doi.org/10.2190/DUGG-P24E-52WK-6CDG

Salovey, P., Mayer, J. D. \& Rosenhan, D. L. (1991). Mood and helping: Mood as a motivator of helping and helping as a regulator of mood. In M. S. Clark (Ed.), Prosocial behavior. Review of Personality and Social Psychology, $12,295-237$.

Schulze, R. \& Roberts, R. D. (Eds.). (2005). Emotional intelligence: An international handbook. Ashland, OH: Hogrefe.

Schunk, D. H., Pintrich, P. R., \& Meece, J. L. (2008). Motivation in education: Theory, research, and applications. Upper Saddle River, NJ: Pearson Prentice Hall.

Stipek, D. J. (2002). Motivation to learn: From theory to practice (4th ed.). Boston: Allyn \& Bacon.

Suter, W. N. (2006). Introduction to educational research: A critical thinking approach. Thousand Oaks, CA: Sage.

Svinicki, M. D. (2004). Learning and motivation in the postsecondary classroom. Bolton, MA: Anker. 
Tan, E. B. (2007). Research experiences of undergraduate students at a comprehensive university. International Journal of Teaching and Learning in Higher Education, 19(3), 205-215.

Tate, M. L. (2004) Sit \& get: Won't grow dentrites: Professional learning strategies that engage the adult brain. Thousand Oaks, CA: Corwin.

Teddlie, C. \& Tashakkori, A. (2008). Foundations of mixed methods research: Integrating quantitative and qualitative approaches in the social sciences. Thousand Oaks, CA: Sage.

Thorkildsen, T. A. (2002). Motivation and the struggle to learn: Responding to fractured lie. Boston: Allyn \& Bacon.

Toohey, S. (1999). Designing courses for higher education. Philadelphia, PA: Open University Press.

Volkening, U., Ostermann, H., Link, L., \& Hubner, H. F. W. (2010). The impact of self-determination on academic motivation of occupational therapists and physiotherapists in continuing higher education in Germany. The Journal of Continuing Higher Education, 58, 85-98. http://dx.doi.org/10.1080/07377361003617319

Wikipedia (n.d.). http://en.wikipedia.org/wiki/Adult_learner. Retrieved March 20, 2010.

Wlodkowski, R. J. (1985). Enhancing adult motivation to learn: A guide to improving instruction and increasing learner achievement. San Francisco: Jossey-Bass.

Wlodkowski, R. J. (1990). Strategies to enhance adult motivation to learn. In M. W. Galbraith (Ed.). Adult learning methods (pp. 97-118). Malabar, FL: Krieger Publishing Company.

Wlodkowski, R. J. (1999). Enhancing adult motivation to learn: A comprehensive guide for teaching all adults. San Francisco: Jossey-Bass.

Wlodkowski, R. J. (2003, Summer). Fostering motivation in professional development programs. New Directions for Adult and Continuing Education, 98, 39-47. http://dx.doi.org/10.1002/ace.98

Wlodkowski, R. J. (2008). Enhancing adult motivation to learn: A comprehensive guide for teaching all adults ( $3^{\text {rd }}$ ed.). San Francisco: Jossey-Bass.

Zull, J. E. (2002). The art of changing the brain: Enriching the practice of teaching by exploring the biology of learning. Sterling, VA: Stylus.

Zull, J. E. (2006, Summer). Key aspects of how the brain learns. In S. Johnson \& K. Taylor. The neuroscience of adult learning. New Directions for Adult and Continuing Education, (110), 1-10. 